\title{
Oil-source rock correlation of reservoir bitumen in deeply buried reservoir of Ordos Basin, China
}

\author{
WANG GUO ${ }^{1}$, GANG CHEN $^{2 *}$, YUHONG Li ${ }^{3}$ \\ ${ }^{1}$ Xi'an Center of China Geological Survey/ Northest China \\ Center for Geoscience Innovation, Xi'an 710054, Shaanxi, \\ China (geology2010@126.com) \\ 2 Department of Geology, State Key Lab. of Continental \\ Dynamics, Northwest University, Xi'an 710069, China \\ ("correspondence: chengangnwu@foxmail.com) \\ ${ }^{3}$ Xi'an Center of China Geological Survey/ Northest China \\ Center for Geoscience Innovation, Xi'an 710054, Shaanxi, \\ China (lyuhong@mail.cgs.gov.cn)
}

Lower Paleozoic gas reservoir in Ordos basin is the key area of deeply buried hydrocarbon exploration and production for china, Meso- to Neo-proterozoic is the potential stratum. The wide development of reservoir bitumen in Ordovician formation is the significant evidence for existence of paleoreservoir in the geological history, which can be regarded as one of the main sources for gas.

The source of bitumen is still unclear because of the influence of high thermal maturity. Here, organic geochemical analyses were performed on 10 bitumen and 6 source rock samples to discuss the oil-source correlation in different areas of basin. The characteristics of C27-, C28- and

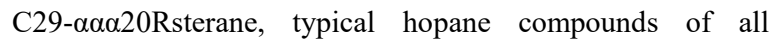
samples are similar and useless for oil-source correlation. The ratios of (pregnane+homopregnane)/C29sterane and tricyclic terpanes/hopanes have high resistance to thermal influence and can be used to effectively differentiate the oil-source correlation into 2 types. In southern area, both bitumen and calcareous mudstone of Ma-6 Section and mudsotne of Neoproterozoic are characterized by higher (pregnane+homopregnane)/C29sterane $(>1.53)$ and tricyclic terpanes/hopanes $(>0.84)$. In middle-eastern area, the bitumen also has higher (pregnane+homopregnane)/C29sterane and tricyclic terpanes/hopanes, but the TOC of calcareous mudstone in this area is too low to generate enough hydrocarbon. In addition, the bitumen of western area and all mudstones of Pingliang Formation are all characterized by lower (pregnane+homopregnane)/C29sterane $(<1.50)$ and tricyclic terpanes/hopanes $(<0.80)$.

We draw the conclusion that bitumen occurring in Lower Paleozoic was mainly generated by sorce rock of Pingliang Formation in most areas and by souce rocks of Ma- 6 Section and Neoproterozoic in regional areas. However, the bitumen in middle-eastern area may be mainly souced by adjacent souce rock under salt. 